\title{
Fanmail vir Breyten
}

Daardie jaar, pas na die klas, (ons het gehoor dat jy al op die rakke was) het ek jou Ysterkoei deur glas gewaar jou uitgestalde woorde deur die raam betas.

Daarbinne was dit knus.

Tussen die boeke het die reuk van sweet en ink gehang. Die winkel was 'n lugballon, 'n lamp, 'n Niet.

Ek was getoor, ek kon dit hoor toe ek my Koei op skuld moes koop.

Vol soos'n uier

het ek die groot geel boek gedra en onder eike wat van winter drup al langs die meulstroom af geloop, geswenk na "Sonop" om die hoek.

Simonsberg staan pril en pers

- ek was nou by die laaste vers terwyl die son met Breyten in my skoot vanuit die Ooste oor my kom.

En sedertdien hoor ek die mondmusiek, proe ek die asem in die Zen van Breytenbundels wat verlig deur winkelvensters wasem.

Zandra Bezuidenhout 


\section{Ontmoeting met b. b.}

Die maan merk die dag in'n melk-reënboogbarokraam.

Montagu: die Prof., die Beckettbrilman, die Voëlman en sy vrou in die byna Spaanshuis met rooiklipvloere en krom mure.

Wyn en eenvoudige fynkos

berei in die binnekring van baiepraatmense

in Afrikaans, Frans, Engels, en 'n bietjie Italiaans.

\section{Hortjies}

Ek sit agter jou hortjies

in die hart van jou venster

agter jou strepies in die tronk.

Ek speel nulle en kruisies

met strepies in jou venster

en wonder hoe jy dink.

Ek drink tee en jy skink lyne.

"om 'n boek sonder woorde en grammatika te skryf".

\section{Meester Metafoor}

Meneer die Digter:

jy wat altyd dwarsfluit speel met elke metafoor:

voor-af, agter-af, onderstebo en bollemakiese.

Nootvas beelde bou,

skilder om elke lyn,

ritmies inkanteer:

vonk-pos, dig-pos,

slakpos, praatpos, boek en doek.

Jy láát ons verstom.

Anne-Ghrett Erasmus 


\section{Karmawiel}

Vanoggend droom ek van die Jesuskind in die Lotusblom. Op ouderdom ses in 'n kinderensiklopedie sien ek 'n wesentjie in 'n ertjiepeul. Is dit gek

om Jesus en Boeddha saam te snoer? Hoe kom dit dat jong kinders lank voor begrip reeds ' $n$ roepende stem hoor deur ou wyshede ontroer word?

Op'n treinreis van Voorsienigheid terug na my rusplek in Tydelikheid sit ek neffens ' $n$ rabbi sonder baard; hy vertel my hoe elkeen na sy aard die goddelike in die lotusblom sien of mag glo aan Christus se bloed; solank ons net weet: uit hierdie gloed van Boeddha, Jesus, wieookal verdien

ons die wete, ek is verbind aan jou in denke, dade en gevoel. Soos jy geheg is aan my in denke, dade en berou: 'n draaiende karmawiel vir jou, vir my.

Joan Hambidge 
Die onbekende ontmoeting

Alexandrië, Egipte, 2007

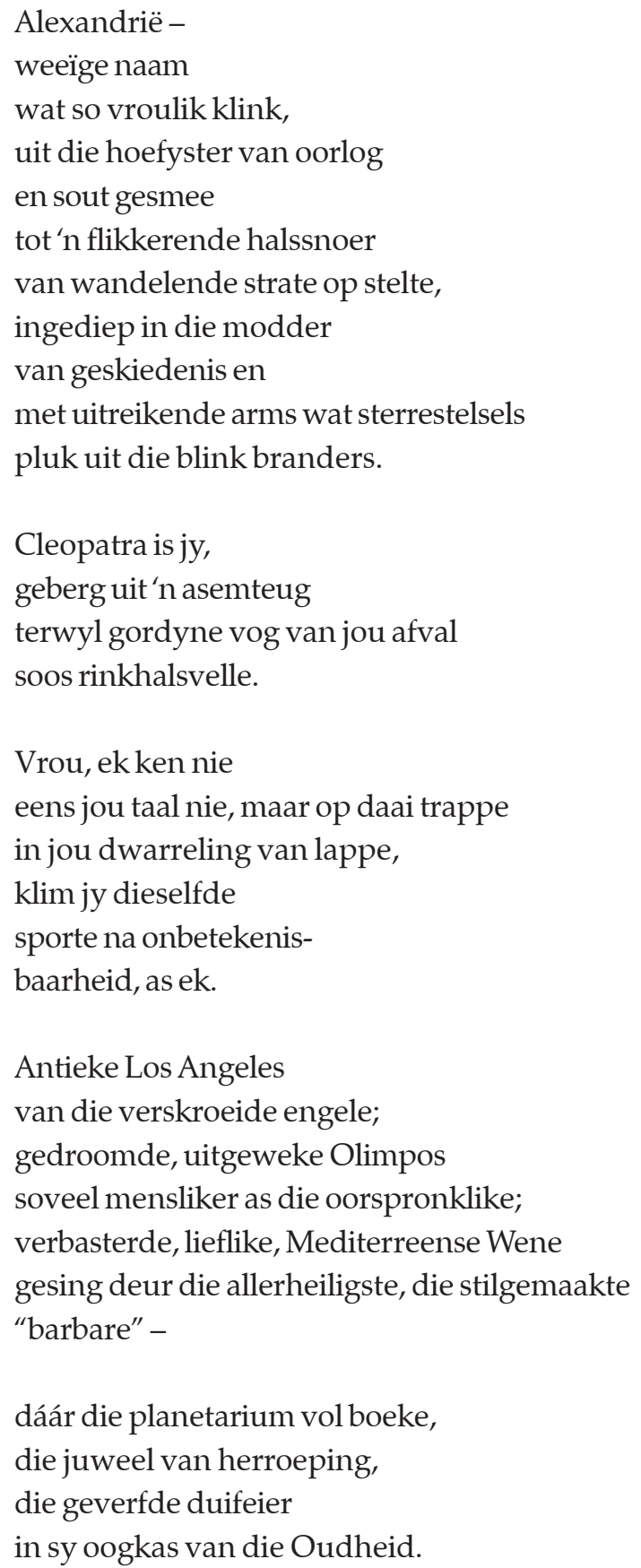


Bruin wieg

van roosblaar en pêrel

is jy -

Jy kyk terug, en ek

kyk vorentoe;

hier in die skerwende

hawe vir vertrekke,

waar verlore wêreldwonders

en hangovers mekaar ontmoet

raak ons mekaar skaars

aan

in die twee skadu's

wat kruis.

Charl-Pierre Naude 